Journal of N.G.S. Vol. 7., 1991 Special issue 1-17

\title{
GEOLOGICAL EFFECTS AND INTENSITY DISTRIBUTION OF THE UDAYAPUR (NEPAL) EARTHQUAKE OF AUGUST 20, 1988.
}

\author{
A. M. Dikshit \\ Department of Mines and Geology, Kathmandu
}

\section{INTRODUCTION}

People of eastern Nepal were shaken off from their beds in the morning of 21 August 1988 at 04 hours $55 \mathrm{~min}$. (local time) when an earthquake was struck in the Udayapur District creating panic in the region. The tremor was felt in larger part of northern India up to Delhi, in Burma and in parts of Bangladesh. In Nepal the tremor was felt for about a minute. The damaged area covered almost all the parts of Eastern Nepal excluding the Higher Himalayas. Damages are reported in Gangtok area of Sikkim, Darjeeling and Kurseong of West Bengal and several cities in the northern parts of Bihar. The event was a reminiscence of the 1934 Bihar-Nepal Earthquake although the magnitude of the latter was much bigger than that of the present one.

\section{Basic Information Regarding the Earthquake are as follows:}

IIC time : 20 August $1988,23 \mathrm{hr} .09 \mathrm{~min} 09.56 \mathrm{sec}$.

Body wave magnitude $\left(\mathrm{M}_{\mathrm{b}}\right)$ : 6.4 Richter

Surface-wave magnitude $\left(\mathrm{M}_{\mathrm{S}}\right)=6.6$ Richter

Epicentre location : Lat $26.775 \mathrm{~N}$, Long $86.609 \mathrm{E}$

Focal Depth : $57 \mathrm{~km}$.

Fig. 1 shows the seismicity of the country and the situation of the main shock. As seen from it, the epicentre lies in the Udayapur District to the south of the Churia Range in the northern part of the Terai plain. Fig. 2 is the focal mechanism solution for the earthquake.

Table 1 lists the major aftershocks of magnitude greater than 4 Richter. Some of these aftershocks also caused some damages to buildings in the epicentral region as well as in the southern cities of Jaleshwar and Lahan.

\section{GEOLOGICAL SETTING}

The area affected by the earthquake encloses different geological and structural associations including the flat lying alluvium of the Terai plains, the sedimentary Siwalik rocks of the Churia Range, 
low and medium grade metamorphic rocks of the Midland and Katnmandu Groups and the crystalline rocks of the Himal Group (Fig. 3).

The Siwalik Group consists of interbedding of fine-medium grained sandstones, gray to greenish gray siltstones and mudstones with very coarse and loose conglomerates with irregular bands of sandstone and clay in the upper part of the section. Reverse faults are responsible for repetition of the beds of this group. The outcrop of this rock unit shows a NW-SE trend in the area to the west of the epicentre. Further to the east of Gaighat, the outcrop of Siwalik rocks makes a conspicuous concave form near the Saptakoshi River. In Chatara-Mechi River stretch the Siwalik outcrops trend more or less east-west.

The Siwalik rocks are separated from the Midland Group of low-medium grade metamorphic rocks by the Main Boundary Thrust (MBT) which trends NW-SE in the area to the west of Saptakoshi and E-W in the area to the east of it, while in the N-S stretch of Saptakoshi, it makes a conspicuous cancave bend.

The Midland Group of rocks crops out as a narrow belt to the north of the MBT. It is overlain . by the rocks of Kathmandu Group which consists of muscovite-biotite schists, quartzites and crystalline limestone with granite intrusions. The rocks of the Midland and Kathmandu Groups are folded into a Megasynclinorium called Mahabharat Syncline which is well seen in Sindhuli-Udayapur area where it plunges in south-easterly direction and in the Ilam-Mulghat area where it plunges in westerly direction.

The northern part of the area is characterized by the presence of the deformed belts of lowmedium grade metamorphic rocks of Midland Group (Ramechhap-Okhaldhunga area) and the two tectonic windows namely the Tumlingtar transverse structure trending NS and the Taplejung Window which trends SE. Both of these are anticlinal structures. It is worth noting that the isoseismals have a conspicuous coincidence with the trends of the Sindhuli-Udayapur Syncline and the Tamor Anticline (Fig. 3)

The crystalline rocks of Himal Group show a conspicuous fringing around the transverse tectonic window of Taplejung.

\section{EARTHQUAKE EFFECTS}

Apart from a toll of 663 human lives lost, the earthquake caused extensive damage to lands, buildings and other infrastructure in the affected area.

Fig. 4 shows the distribution of earthquake intensities in Modified Mercalli (MM) scale. The epicentral intensity was in the upper range of VII MM. Isoseismalls of V to VIII MM were mapped rigorously in the affected area. An east-west trend of the isoseismal with conspicuous northward bend in the eastern as well as western parts of the affected area is obvious. The epicentre itself falls in the intensity VII area which is due to the fact that the fault rupture plane is dipping steeply towards south (Fig. 2). The epicentral intensity extends more towards east than towards west of the epicentre. 
Table 1 List of Major Aftershocks of Magnitude

Greater than 4 Richter

(Source: Seismological Laboratory, DMG)

\begin{tabular}{lccccc}
\hline Local Date & $\begin{array}{c}\text { Local Time } \\
\text { Hr: Min }\end{array}$ & $\begin{array}{c}\text { PKI } \\
\text { Duration, }\end{array}$ & $\begin{array}{c}\text { DMG } \\
\text { Duration } \\
\text { Magnitude } \\
\text { MD }\end{array}$ & $\begin{array}{c}\text { USGS } \\
\text { Mb }\end{array}$ & $\begin{array}{c}\text { Magnitude } \\
\text { MS }\end{array}$ \\
\hline $21-08-1988$ & $05: 24$ & 18 & 5.0 & - & - \\
$22-08-1988$ & $17: 20$ & 12 & 4.5 & 4.3 & - \\
$24-08-1988$ & $15: 41$ & 16 & 4.9 & 4.7 & 4.1 \\
$29-08-1988$ & $17: 57$ & 10 & 4.3 & - & - \\
$02-09-1988$ & $03: 49$ & 12 & 4.5 & 4.6 & - \\
$02-09-1988$ & $12: 20$ & 18 & 5.0 & 4.3 & - \\
\hline
\end{tabular}

Table 2 Areas under different intensity zones

\begin{tabular}{cc}
\hline $\begin{array}{l}\text { Intensity (Modified } \\
\text { Mercalli, MM) }\end{array}$ & Area, Sq Km \\
\hline VIII (epicentral) & 2532 \\
VII & 7202 \\
VI & 12944 \\
V & $>23000$ \\
\hline
\end{tabular}




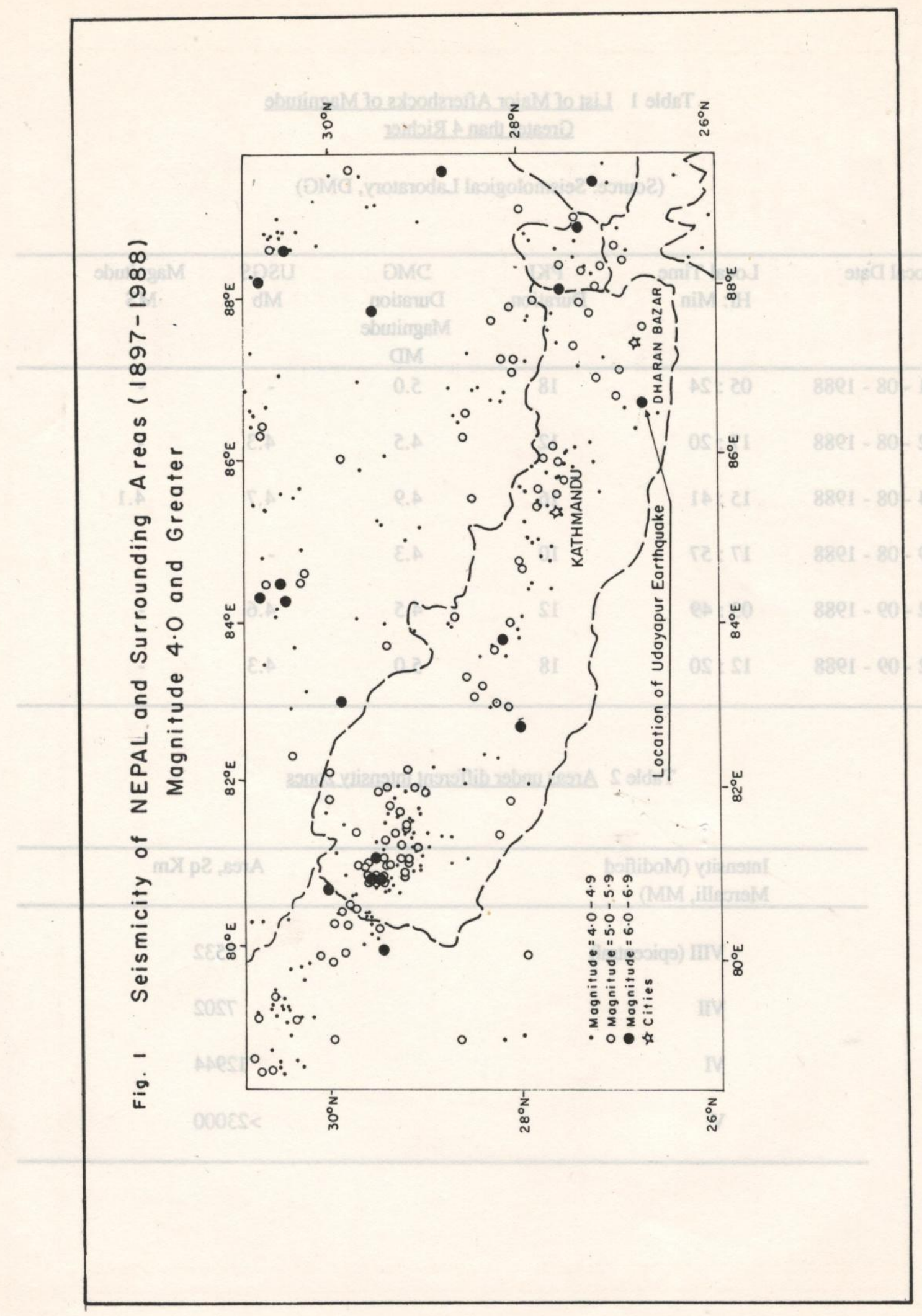




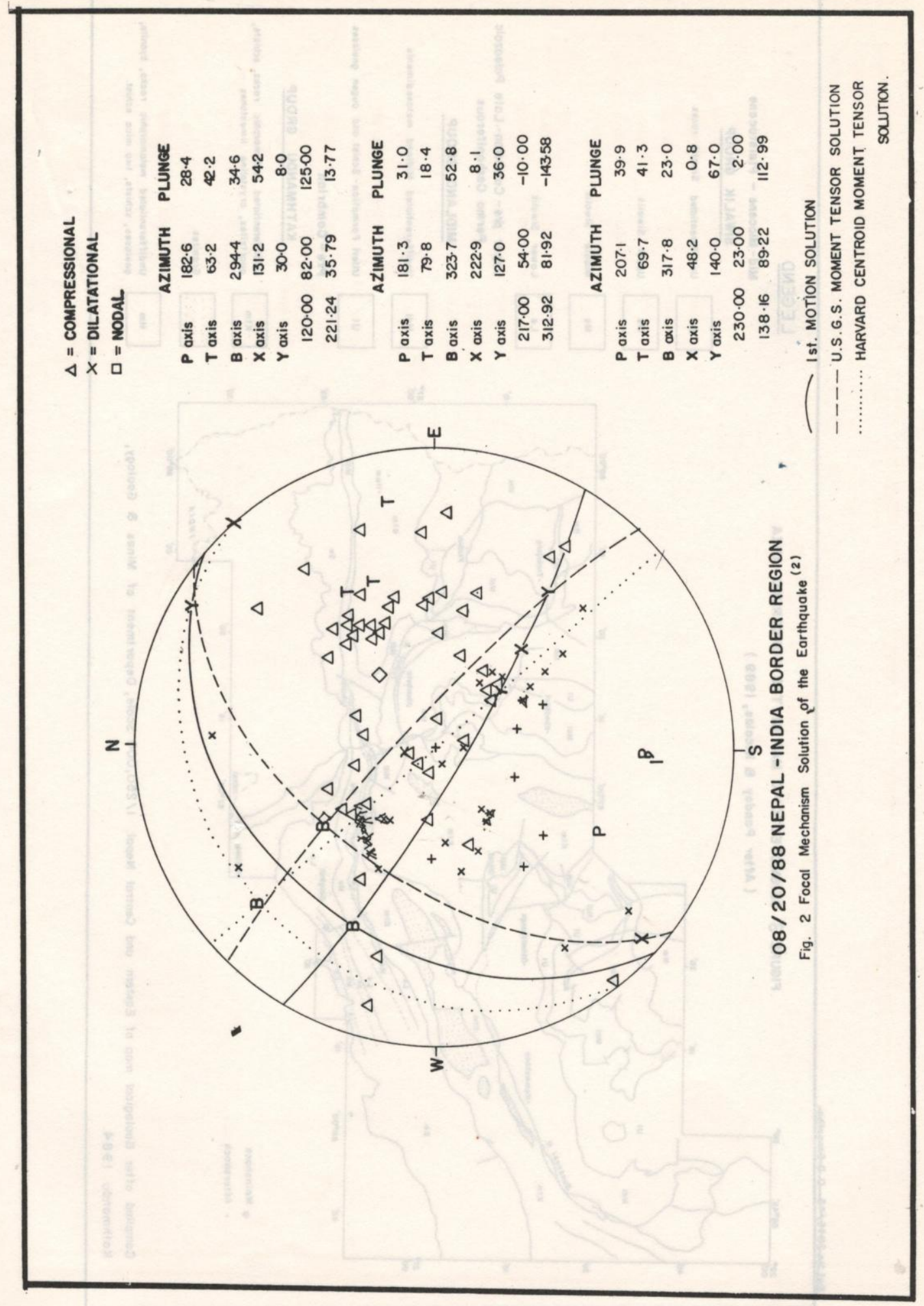




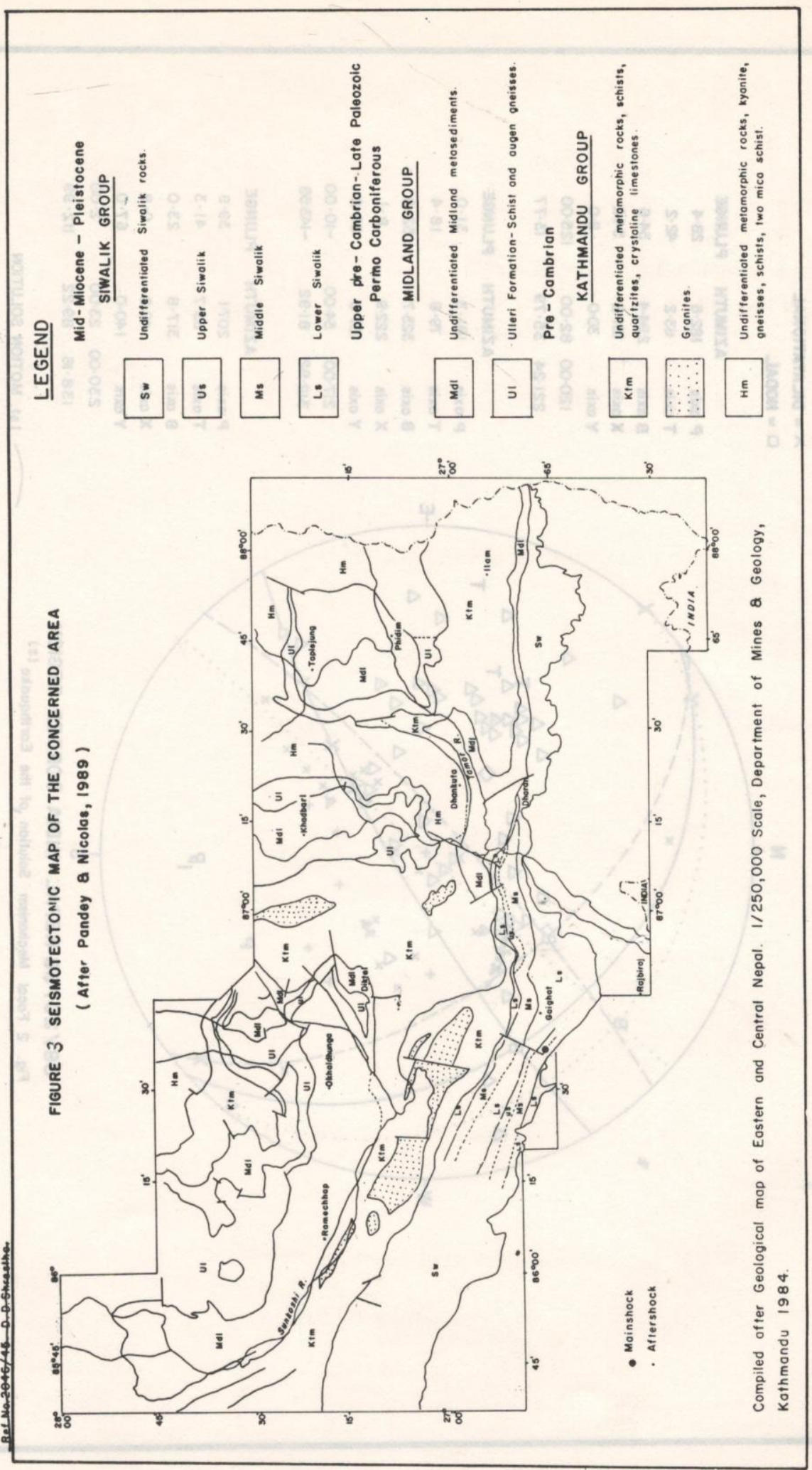


Attenuation in north-south direction is about three times faster than in the east-west direction (Fig. 4). Table 2 shows the areas of territories lying in various intensity zones.

\section{Ground Fissuring}

The earthquake did not produce any surface rupture. However, fissuring of land was prolific both in the Terai plains and in the mountains especially within the isoseismals of VI - VIII MM. In the mountainous terrain, the fissures are located mainly along the ridges, mostly placed en echelon, and in the upper parts of the hillslope. In the latter case, some downslope displacement of the colluvial soil blanket was seen. On rectilinear slopes such fissures were seen developed at random along the whole of the slope length. The length of the individual segments of such fissures ranged from 10 to $50 \mathrm{~m}$ while the width varied from 2 to $60 \mathrm{~cm}$. In the areas of carbonate rocks such as in Murkuchye Village, fissures were developed due to the collapse of caverns and the relative displacement of the remnant karstic blocks.

Such fissures caused the following concern for the local people in the mountainous region:

- the fissures damaged the hill irrigation canals at many places resulting in the increased leakage,

- degradation of the cultivated land because of reduction in water holding capacity,

- increased risk to cattle grazing due to the fissures,

- increased possibility of landsliding.

In the Terai area the fissures were generally found to be associated with liquefaction and embankment failure.

\section{Landslides}

The Sindhuli-Udayapur-Bhojpur area of eastern Nepal generally falls in the high landslide hazard category. So it was but natural to expect increased instance of landslides triggered by the earthquake. Field mapping confirmed this fact. Numerous landslides were triggered by the earthquake especially within the isoseismals of VIII and VII (Fig. 4) although the farthest one triggered by the event lies at an epicentral distance of $130 \mathrm{~km}$. Most of the landslides are of debris slide and rock fall types although slumps in thick soil blanket are not uncommon. Debris flow and debris avalanche were triggered limitedly in the epicentral intensity area only.

No casualties due to the seismically induced landslides were reported. However, the damage to the land and forest as well as to the roads, trails and canals is enormous especially within the isoseismals of VII-VIII, where landslide risk to villages and individual houses have increased greatly. 
Liquefaction was observed only in the alluvial plains of the Terai where it manifested as ground oscillations, lateral spread and sand boils.

Opening and closing of fissures in the flat ground with some ejection of muddy water was reported by local residents from the northern part of Siraha District which is close to the epicentral region. Probably people were talking about ground oscillation which results from liquefaction in the underlying soil leading to a to-and-fro movement of the decoupled overlying soil blocks.

Lateral spread was observed in limited areas. It was seen at Biratnagar and Katari where the gently inclined ground was displaced horizontally into pond or riverside with the development of tension cracks at the back. Damage to the southern part of the townhall at Biratnagar is an example of this phenomena. The contraction and failure of several bridges along the Mahendra Raj Marg could also be attributed to the phenomena of lateral spread which resulted in the displacement of the alluvial deposits of the banks into the free face of river channel incision.

The most widespread of the phenomena of liquefaction was the sand boiling. These were pervasive in the Terai plains from Simraugarh of Bara District in the west to Gauriganj of Jhapa District in the east. Highest extent of boils was seen in the districts of Dhanusha and Siraha where as many as 1000 craters per square kilometre of area were observed. The sand craters were usually couple of tens of centimetres to some metres in diameter. The ejection of water and sand from some of the craters in Siraha district is reported to be so forceful that the ejection height reached upto $1 \mathrm{~m}$. The ejected sand is fine, uniform and the colour is usually yellow to gray (Fig. 5). Ejection of sand and water were also seen along fissures oriented en echelon usually in the north-south and east-west directions. A 4-10 m wide zone extending over $3 \mathrm{~km}$ length with discontinuous fissures was mapped in the left bank of the Balam River in the Saptari District.

Sand Intrusion into Wells

An overwhelming majority or the dug and tube wells in the area subjected to sand boils were filled up with sand creating an acute shortage of drinking water. In the north-eastern part of Siraha District, nearly all of the bamboo borings, driven for tapping shallow artesian water for irrigation, ejected sand and were clogged. Many of the tube wells started delivering sandy water even without being pumped. In Jhapa District many such wells were found to be bent at the depth of 2-3 m necessitating reboring.

\section{Damage to Building}

The most important type of damage from the earthquake was done to the buildings. This damage is solely responsible for all of the injuries and casualties. Structural damage to the buildings was caused mainly by the ground vibration but liquefaction and seismically induced landslides were also responsible for the collapse of buildings in the Terai and hilly regions respectively. No instance of fire during the earthquake was reported. 


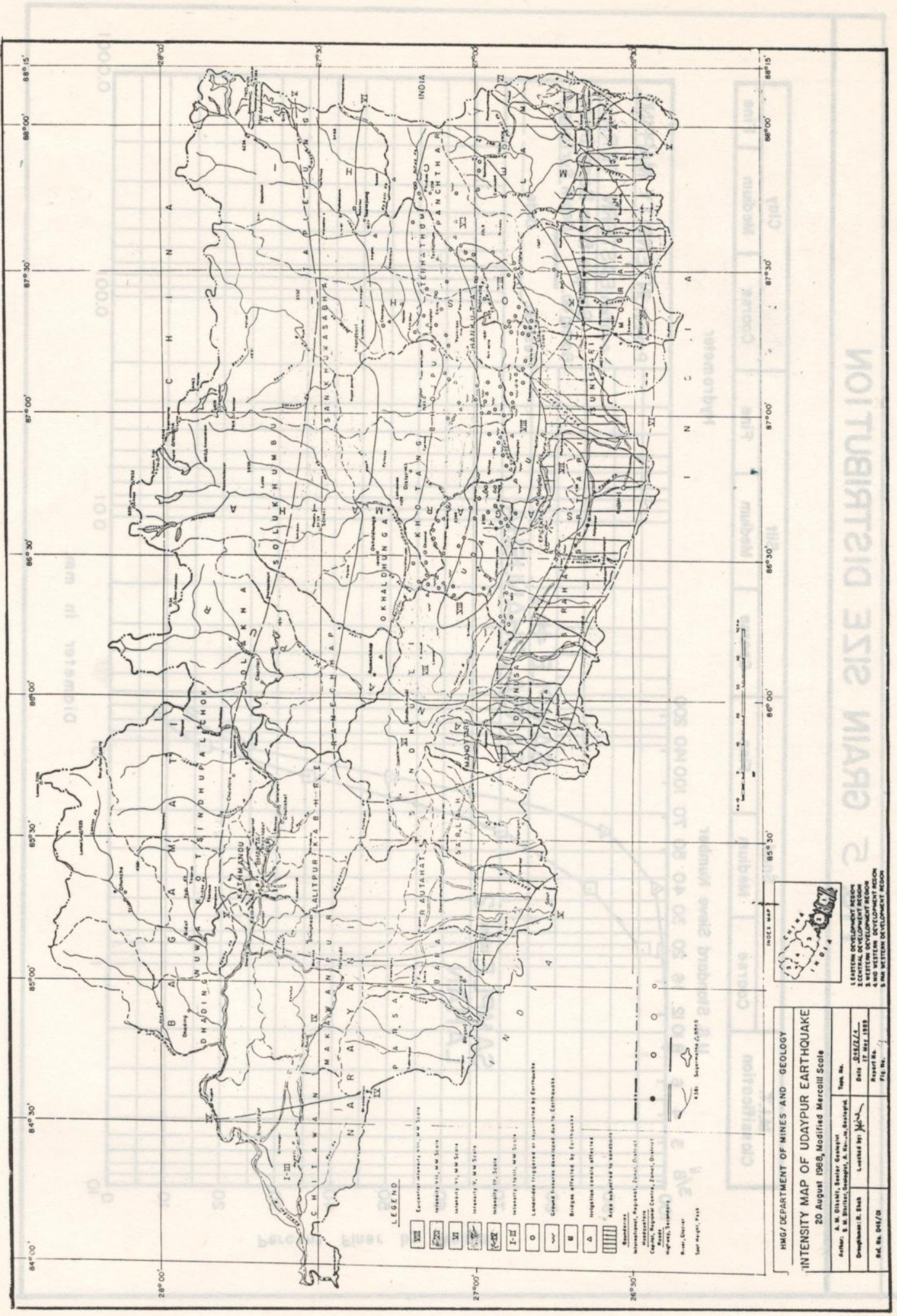




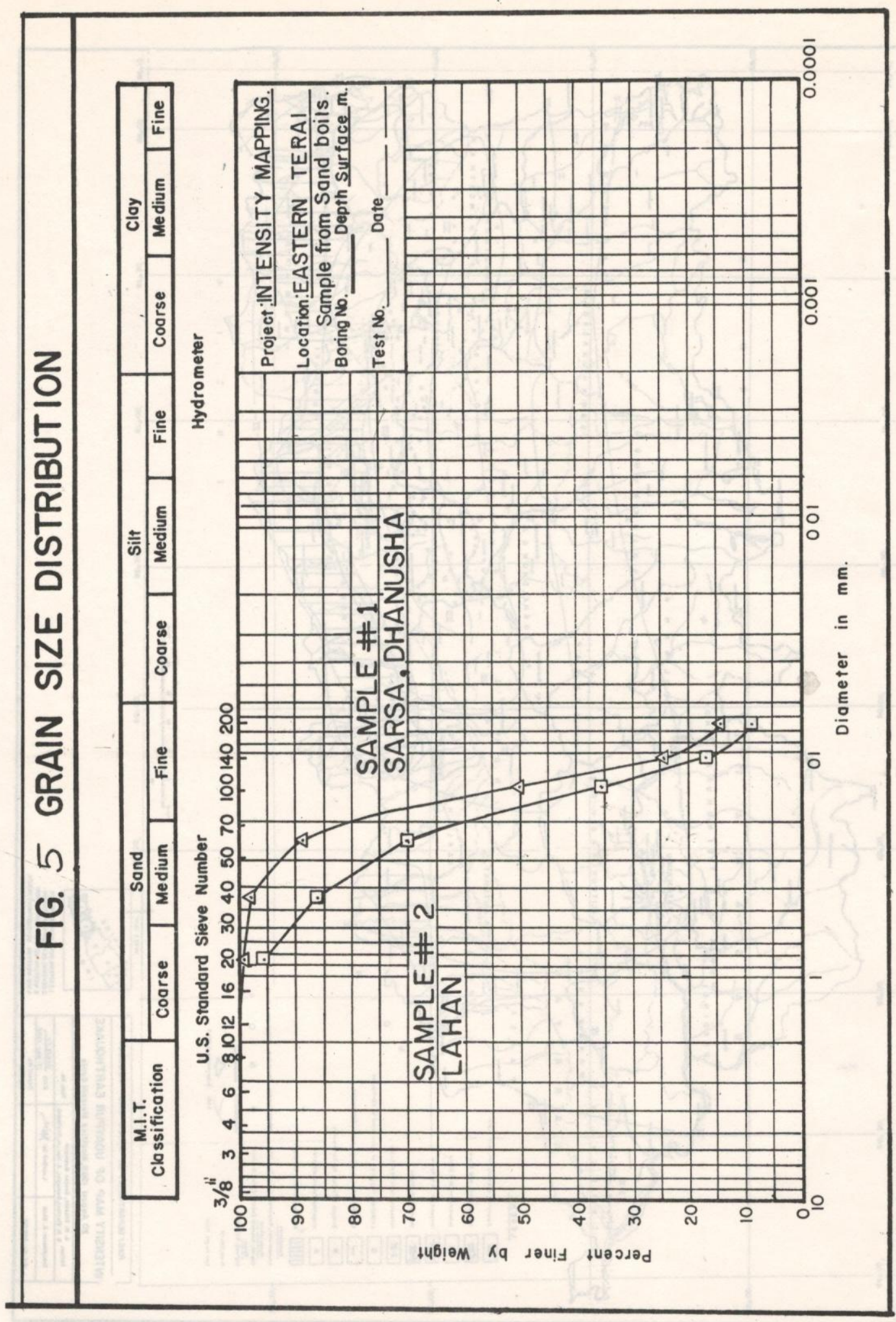


Generally, the extent of damage is dependent upon the intensity levels and epicentral distance. But one of the most important factors which determined the damage intensity was the age and technology of construction. The following types of construction are prevalent in the affected area.

A. Adobe - generally without foundation, $30-40 \mathrm{~cm}$ thick mud walls, thatched roof, earthern floor. Typical locality: the Terai villages.

B. Wood Framed Buildings - foundation is usually timber piles driven $1 \mathrm{~m}$ into the ground; the structure is a combination of vertical and horizontal timber beams; walls either mud plastered, bambo mesh or timber planks veneer; sometimes all wood structure. Typical locality: the Terai villages.

C. Brick Masonry Building - clay brick, unfired (C1) or fired (C2), in mud or surkhi (lime \& brick dust)/cement mortar, without any reinforcement, strip masonry foundation, floor on timber beams or reinforced brick concrete slab, height 3-12 m. Typical locality: market places in Terai and hills.

D Stone Masonry Buildings - stone masonry, usually undressed stones, in mud (D1) or rarely cement mortar (D2), no reinforcement, foundation $1.5 \mathrm{~m}$ wide, $1 \mathrm{~m}$ deep stacked stone blocks in mud mortar, earthern floor on timber beams or reinforced brick cement slab, roof usually slate or galvanized iron sheets or thatch on wooden rafters, height 3-12 $\mathrm{m}$ (1-4 storied). Typical locality: throughout the hilly region and at the foothills.

E. Reinforced Concrete Frame Buildings - isolated concrete pad footing, unreinforced brick shear walls in cement mortar, floor on reinforced brick concrete (RBC) or reinforced concrete (RC) slab.

No statistical analysis as to the intensity level and the number of damaged buildings of particular construction technology was carried out in this study. However, it can be said that serious damage to buildings was seen mostly in the intensity zones of VI-VIII MM. In areas of lower intensities, the damage to buildings could mostly be related to especial circumstances such as poor construction technology, old age of the structure, pre-existing unstable ground and in some cases, liquefaction of the underlying soil.

In epicentral intensity area masonry buildings with mud mortar sustained the maximum damage and collapse. Serious cracks and partial collapse and fall of plasters were observed in cement mortared masonry constructions. Wood framed buildings were seriously tilted. However, reinforced concrete frame buildings did not show appreciable damage except in some cases. 
In the VII MM intensity zone, the unit masonry walls in mud mortar sustained partial collapse. A majority of the buildings of such construction have shown the development of objectionable cracks in the walls and out-of-plumbing of the latter. A lot of debris slides were triggered by the earthquake in this intensity level in the hilly regions. Such slope instability was responsible for the collapse of buildings in many hilly villages such as Basantapur, Sidhuwa, Hile, etc. of Dhankuta District and Pangcha of Bhojpur District.

Cement mortared unit masonry as well as reinforced concrete frame structures fared rather well in this intensity level.

In intensity zone of VII MM, the unreinforced wooden (B1) or stone masonry buildings (D1) showed objectionable cracks in the walls with partial collapse in the upper storeys. Such collapses were usually responsible for the injuries and deaths in this intensity level in the hills. In the Terai region, adobe buildings of type A collapsed extensively although the structure is usually one storeyed only. Brick masonry structures (type C) developed cracks in the walls. 2-3 m high brick fences collapsed rather extensively.

\section{Damages to Infrastructures}

Various degree of damage was inflicted by the earthquake on various infrastructures such as roads, bridges, irrigation canals, deep tube wells, hydro-electricity projects, etc.

Almost all the motorable roads in the south-eastern part of the country sustained damages of various extent mainly due to liquefaction, groundfissuring, landsliding and road embankment failure. Table 4 summarises the damages to the various roads.

A majority of the culverts in Kamala-Bering khola stretch of the Mahendra Raj Marg (MRM) showed conspicuous displacement of the approach slabs. Such displacement was accompanied by a settlement of $10-25 \mathrm{~cm}$. Displacement of individual spans of the multispanned bridges were noticed at many rivers along the MRM. A shortening of the bridge span by $17 \mathrm{~cm}$ was monitored at Gehri bridge east of Lahan. Here the deck hit into the right abutment, caused partial shear failure in it with the development of a horizontal tension crack at its lower part. The right terminus of the bridge deck got off from the pad and the bridge was inoperable for several months. Similar development of fissures in the abutment walls and partial shear failure in deck resting pads were observed at the bridges across Ratua, Mawa and Duhabi rivers. But these bridges were still operable after the earthquake event.

Many of the hill irrigation canals in intensity zones VII-VIII MM were affected by the earthquake. Majoarity of the affected ones were breached or covered by the induced landslides and others started leaking along the widespread fissures due to which more landslides were generated subsequently. The headrace canal of the Taplejung Mini Hydroelectric Project was found to be breached. Leakage from the reservoir of the Bhojpur Mini Hydroelectric Project is believed to be due to the generation of fissures across the reservoir rim during the earthquake. 
The only irrigation canal inspected in the Terai was the Kamala (west) canal. It showed the development of 1-3 cm wide horizontal longitudinal cracks along the side wall and longitudinal vertical fissures in the bed. Minor distributory canals were reported to have affected at many localities in the Terai.

Several of the electric pylons of the Taplejung Mini Hydroelectric Project were tilted and required correction. However, the high voltage pylons of the national power grid, along the MRM in the Terai region, were not seen affected.

\section{Long Period Effects}

The damage to several houses at Bhaktapur and the generation of 0.2 million cu $\mathrm{m}$ slump at Chainpur of Sankhuwasabha District are believed to be due to the low acceleration high displacement waves of longer period which might have coincided with the natural periods of the affected structures or ground. These sites have poor geological conditions and they lie at an epicentral distance of about 165 $\mathrm{km}$. Long stretches of land in between these sites and the epicentre did not show such effect and the damage is much less.

\section{Unusual Effects}

Many instances of low quality older buildings being less affected than better quality new buildings in same localities were seen. The township of Tehrathum is a striking example. Similarly the destruction of buildings at Hulak Tol of Dhankuta town was much more severe than at other blocks although a majority of the buildings in the town are of similar age, quality and type as the damaged ones. Such unusual effects were seen in many localities within the same intensity zones. Site geology and hydrogeology as well as extent of liquefaction, construction quality etc. may be the special circumstances leading to such visibly anomalous effects.

The unusual reported case of the Sunkoshi River flowing upstream during the earthquake in the north-eastern part of Udayapur District might have taken place due to the backwater effects of landslides dams which partially blocked the river momentarily. Two such landslide dams were reported to have been formed during the earthquake in the downstream stretches of the Sunkoshi River.

\section{Casualties and Injuries}

Casualties and injuries due to the damages by the earthquake in various administrative districts of the country are summarised in Table 3 .

\section{CONCLUSIONS}

The isoseismals show elongated pattern in east-west direction. The trend is NW-SE in the western part and SW-NE in the eastern part of the affected area. These trends correlate well with the trend of geological structures of the area. The attenuation across the geological trend is much faster than along it. 


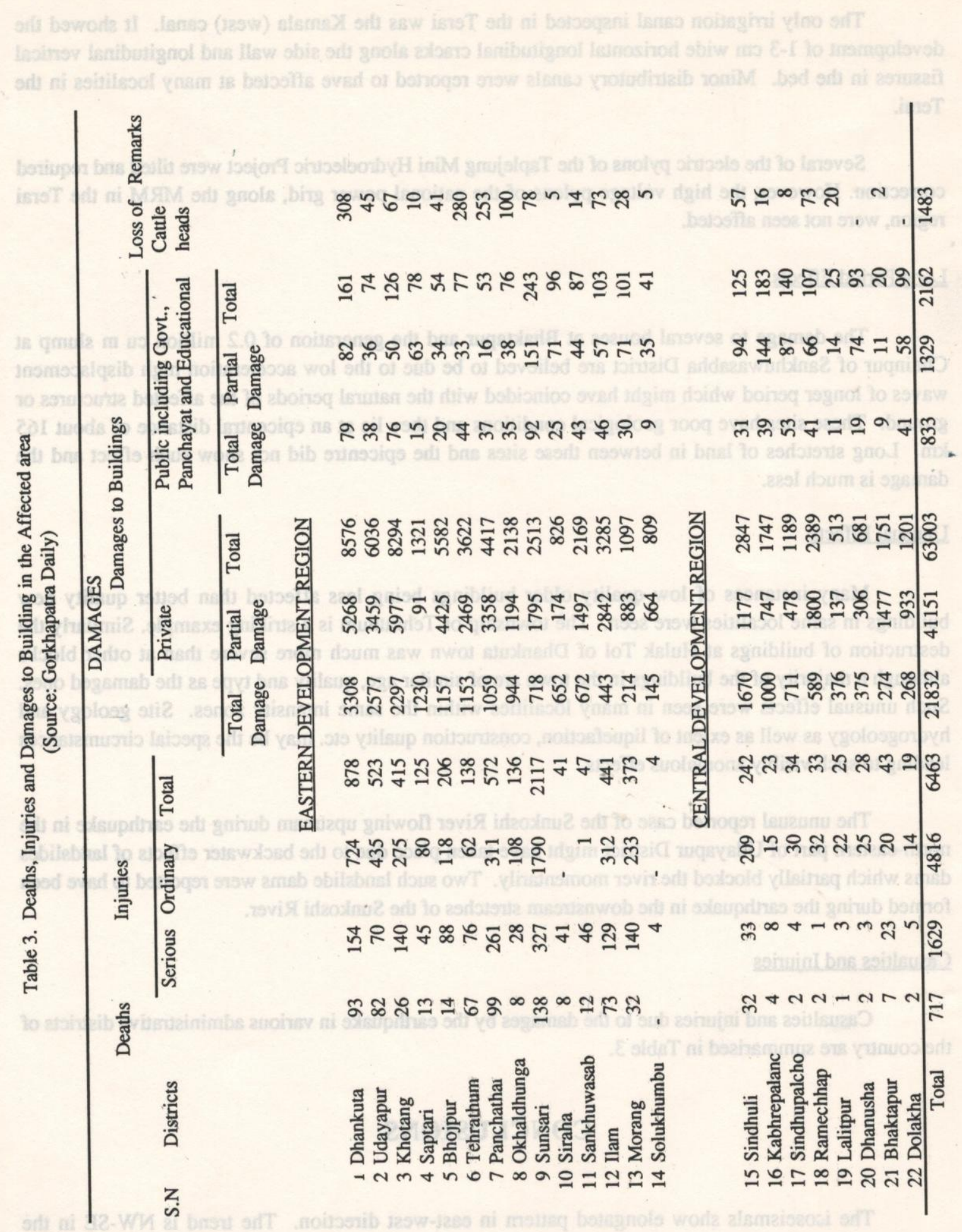




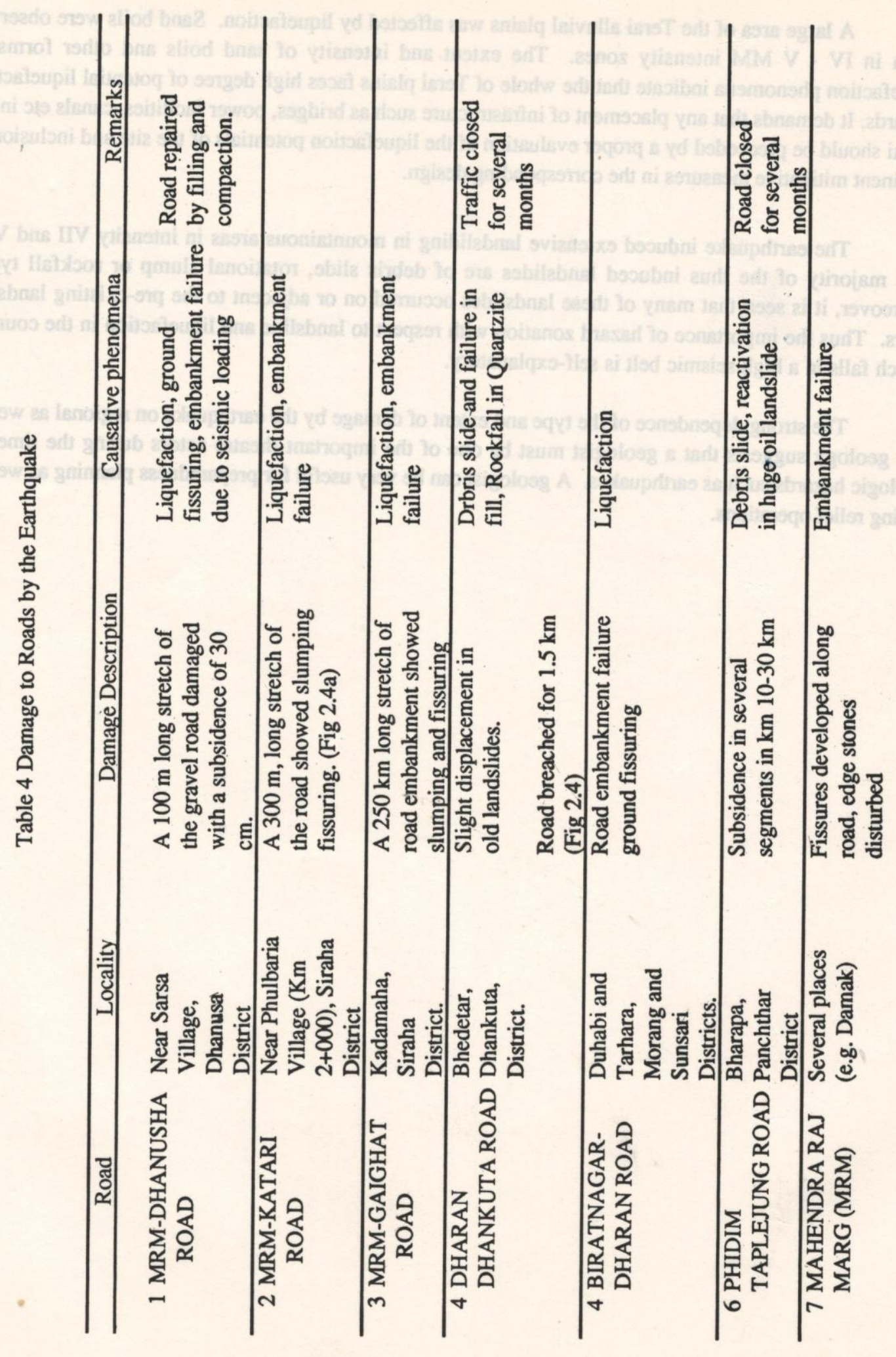


A large area of the Terai alluvial plains was affected by liquefaction. Sand boils were observed even in IV - V MM intensity zones. The extent and intensity of sand boils and other forms of liquefaction phenomena indicate that the whole of Terai plains faces high degree of potential liquefaction hazards. It demands that any placement of infrastructure such as bridges, power facilities, canals etc in the Terai should be preceeded by a proper evaluation of the liquefaction potentials of the site and inclusion of pertinent mitigative measures in the corresponding design.

The earthquake induced extensive landsliding in mountainous areas in intensity VII and VIII. The majority of the thus induced landslides are of debris slide, rotational slump or rockfall types. Moreover, it is seen that many of these landslides occurred on or adjacent to the pre-existing landslide scars. Thus the importance of hazard zonation with respect to landslide and liquefaction in the country, which falls in a high seismic belt is self-explanatory.

The strong dependence of the type and extent of damage by the earthquake on regional as well as site geology suggests that a geologist must be one of the important theatre actors during the times of geologic hazards such as earthquakes. A geologist can be very useful for preparedness planning as well as during relief operations. 


\section{ACKNOWLEDGEMENT}

The author expresses his gratitude to Mr. M. N. Rana, Director General of Department of Mines \& Geology for permitting the use of the Departmental reports and maps in this paper. His guidance and encouragement are also gratefully acknowledged.

\section{REFERENCES}

Andrews, C.F., 1935. The Indian Earthquake, George Allen \& Unwin Ltd, London, pp. 130.

Gorakhapatra Daily, August 1988 to March 1989. Various news items, Gorakhapatra Sansthan; Kathmandu.

Pandey, M. R. and Nicolas, M., 1989. The Aftershocks Sequence of the Udayapur (Nepal) Earthquake of August 20,1988; Department of Mines \& Geology, Kathmandu/ Laboratoire De Geophysique, Paris (Unpublished).

Thapa, N., 1989. Bhadau Panch Ko Vookampa 2045; (The Earthquake of 5th Bhadra, 2045 B.S., in Nepali); Niranjan Thapa, Kathmandu.

Updike, R. G.. Preliminary Trip Report; UNESCO-USGS Cooperative Scientific Mission to Nepal to Assess the 1988 Udayapur Earthquake, (Unpublished). 